\title{
BUDGET DEFICIT AND PUBLIC DEBT IN THE BALTIC STATES IN 2010-2015
}

\author{
STANISEAW PILŻYS', ROBERT ALIUKONIS ${ }^{2}$
}

\begin{abstract}
The economic crisis of 2009 sparked a sharp increase in deficits and public debt among most EU countries. While states with different capacities and fiscal policies intervened to alleviate the effects of the crisis, results varied. This article focuses on macroeconomic developments, including public deficit and debt in the Baltic States: namely, Lithuania, Latvia, and Estonia. The main purpose of this analysis is to examine the level of deficit and public debt between 2010 and 2015. We also seek to examine the relationship between deficit and public debt levels and GDP growth rate. We rely on statistical and comparative analyses. We compare domestic deficit and debt figures to the average among EU member states. Our statistical analysis reveals no high correlation between the growth of GDP and reduction of the budget deficit in the three countries. This largely depends on the public finance policy pursued by the government.
\end{abstract}

\section{Keywords}

Public debt; budget deficit, public deficit

JEL Classification: H69, E62, 057

\section{Introduction}

The economic crisis of 2009 sparked a sharp increase in deficits and public debt among most EU countries. While states with different capacities and fiscal policies

1 Research-and-teaching assistant at the Department of Economics, Faculty of Economics and Informatics in Vilnius, University of Bialystok, Lithuania-Poland. The Author specializes in macroeconomics, energy economics, and energy finance. He is the author of 11 reviewed articles in economic journals and books. Contact email: s.pilzys@uwb.edu.pl.

2 Research-and-teaching assistant at the Department of Economics, Faculty of Economics and Informatics in Vilnius, University of Bialystok, Lithuania-Poland. The Author specializes in marketing. He is the author of 5 reviewed articles in economic journals and books. Contact email: r.aliukonis@uwb.edu.pl. 
intervened to alleviate the effects of the crisis, results varied. This article focuses on macroeconomic developments, including public deficit and debt, between 2010 and 2015 in the Baltic States: namely, Lithuania, Latvia, and Estonia.

The Baltic states only recently became a part of Western European politics, joining the European Union and the North Atlantic Pact. Since 2004, many Baltic states have met convergence criteria and introduced the Euro: Estonia in 2011, Latvia in 2014, and Lithuania in 2015. It's important to note that deficit and public debt are one of the most critical components of the convergence criteria, which makes our study particularly interesting. The main purpose of this analysis is to examine the level of deficit and public debt between 2010 and 2015. We also seek to examine the relationship between deficit and public debt levels and GDP growth rate. We rely on statistical and comparative analyses. We compare domestic deficit and debt figures to the average among EU member states. The data for this analysis was sourced from Eurostat and the financial institutions of surveyed countries, including finance ministries, treasuries, central banks, and state statistical offices. In addition, we also considered International Monetary Fund reports throughout our analysis.

\section{Theoretical Issues of Budget Deficit}

The state budget is critical in the public finance system. It accumulates the largest share of public sector finances, making the state government the main body of the political, social and economic system (Owsiak, 1999: 91).

As the theory of public finance evolved, the definition of the state budget changed. Today, a budget is defined as "a set of accounts showing for every calendar year any permanent receipts and burden on the state" (Gaudemet, 1990: 178). This definition implies that the budget can be understood as a numerical description of the state's economic and financial system, meaning that it can be shaped and controlled. The economy may be in a state of equilibrium, deficit, or surplus.

The state budget is a statement of revenue and expenditure for various public purposes. The state's revenue is generally sourced primarily from direct taxes on corporate profits and individual citizens' incomes, as well as from indirect taxes paid on purchased goods. The main state expenditures go to national defense, education, culture, health care, social security payments, and interest paid on internal and external debt (Nasiłowski, 1998: 211).

The state budget, as both a monetary and a legal fund, can be considered as a normative economic act and the legal basis for government activity. Three basic budgetary functions are worth noting: 
1. the allocation function, which involves collecting income and making expenditures by changing the structure of the produced social product,

2. the redistribution function, which occurs when the state budget divides taxes between citizens and the state,

3. and the stabilization function, which occurs when the budget alleviates the negative effects of economic fluctuations to ensure sustainable and stable economic growth.

The state budget requires special rules, one of which is the principle of balancing: that is, balancing the budget in such a way as to not generate a deficit. A state with a balanced budget is one in which a state's total expenditures perfectly match its income (Kańduła, 2006: 91). "In the literature of the subject, it is often also assumed that budget imbalance occurs only in the case of a deficit. The budget in which there is a surplus of expenditure is considered balanced" (Owsiak, 2005: 295). The European Union's budget is created by balancing expenditures with income. Thus, surplus and budget deficits are not possible given the EU's budget planning and implementation.

Budget surpluses are rare; in most countries, there are instead budget deficits. The cause of the deficit may be due to excessive budget expenditures or low income. For today's international economics, unpredictable fluctuations in economic conditions are a constant risk. Hence, states tend to overestimate budget revenue in anticipation of high expenditures (Nasiłowski, 1998: 212-213).

There is no clear answer in the literature on the extent to which budget deficits are acceptable or beneficial to state economies. Views of economists are often contradictory. In their joint work in Economics, Paul Samuelson and Wilhelm Nordhaus quote the "father of economics" Adam Smith, who argues that "the only good budget is a balanced budget". On the other hand, $20^{\text {th }}$ century economist Warren Smith argues that "the only correct rule is that the budget should never be balanced" (Samuelson, 1995: 263).

Prior to the 1930s, there was an assumption that balanced budgets created only positive benefits. However, this was challenged by J.M. Keynes (2003), who argued that disparities between investment and consumer demand and the supply of goods in the developed market economy meant that balanced budgets may lead to prolonged recessions.

The 1992 Maastricht Treaty defined the economic indicators and principles that must be satisfied to join the Economic and Monetary Union. The requirements were later called Maastricht criteria or convergence criteria. In addition to the central 
bank's independence, countries are obliged to meet the following four criteria: price stability, fiscal stability, exchange rate, and interest rate terms.

According to the Treaty, the condition of a potential member state's public finances is of critical importance. The Member State must not be covered by the excessive deficit procedure (EDP), which occurs when general government indicators are exceeded. These indicators amount to $3 \%$ of GDP as compared to deficits and $60 \%$ of GDP in public debt. In practice, the assessment takes into account a sate's trajectory towards these values rather than individual values at a single point in time. There is also the added challenge of reforming the budget to meet standards. Decisions on fiscal policy have not been precisely defined and therefore can be undertaken by states independently.

\section{Theoretical Issues of Public Debt}

Public debt is not a new phenomenon. There are in fact numerous studies on the impact of public debt on the economy and state policy. In the literature, public debt is defined as the "financial commitment of public authorities (state and local government) to loans". Some economists broaden the definition of public debt by including "hidden debt" that involves the state's debt to citizens in the form of future retirement payments, social benefits, and the maintenance of the health care system (Siwińska-Gorzelak, 2015: 14).

The financial obligations of the state include primarily borrowing money, issuing loans, and accepting deposits and state-issued securities. Public debt can be divided using the following four criteria:

1. source of funding, such as internal (domestic) and external (foreign),

2. the type of state unit that draws the debt (central government, local government or social security funds),

3. the principles of gross or net debt records and

4. the debt's longevity.

For the purpose of this article, the debt will be considered primarily with regard to structure, debtors, debt servicing costs, and the debt ratio to deficit and GDP growth.

Public debt is directly linked to the budget deficit. Public debt can adversely affect economic growth and international competitiveness, so its reduction often becomes the main goal of government financial policy. On the other hand, public debt can also be regarded as a policy instrument of a given state's government. Public debt is 
a "capital mass in respect of which the state obtains a temporary right of ownership, including the right of redistribution" (Waśniewski, 2014: 45). This is a very complex and multi-faceted macroeconomic issue. For example, when referring to internal public debt, citizens who are sovereigns of the state are both creditors and debtors when guaranteed repayment of the debt by the state.

The literature on negative consequences of public debt growth includes the displacement of private investment, foreign dependence through external debt, tax efficiency losses, slow economic growth, and limits on the implementation of large government programs (Zagóra-Jonszta, 2015: 157).

The main causes of public debt include:

1. state borrowing in subsequent periods of the budget deficit,

2. increase in public expenditures as a result of wars, natural disasters, or major economic crises,

3. implementation of state policy that involves increasing public expenditures in order to stimulate prosperity,

4. the debt trap or

5. achieving policy goals through increased redistribution of citizens' incomes without limiting another state spending (Daniłowska, 2008: 111-112).

We assess the level of public debt by comparing public debt to GDP, where a debtto-GDP ratio of $50 \%$ is considered critical. In addition, we consider the ratio of debt to exports (critical value $275 \%$ ), debt-service-costs-to export-ratios (critical value $30 \%$ ) and interest-to-export ratios (critical value 20\%). A country is considered to be seriously indebted when three of the four indicators exceed critical values. The state is considered to be moderately indebted when three of the four indicators exceed $60 \%$ of the critical values (Daniłowska, 2008: 112-113).

\section{Public Deficit in the Baltic States}

Between 2010 and 2015, the public deficit in the Baltic states varied drastically. Chart 1 shows that Estonia fell against other Baltic countries as well as the EU average. The highest deficit was Lithuania in 2011, after which it experienced consistent improvement. To better understand how the deficit changed throughout the Baltic States, it is worth considering each state individually. 


\section{Chart 1 Comparison of Public Deficit in Estonia, Lithuania, Latvia and EU} Average of $28, \%$ of GDP

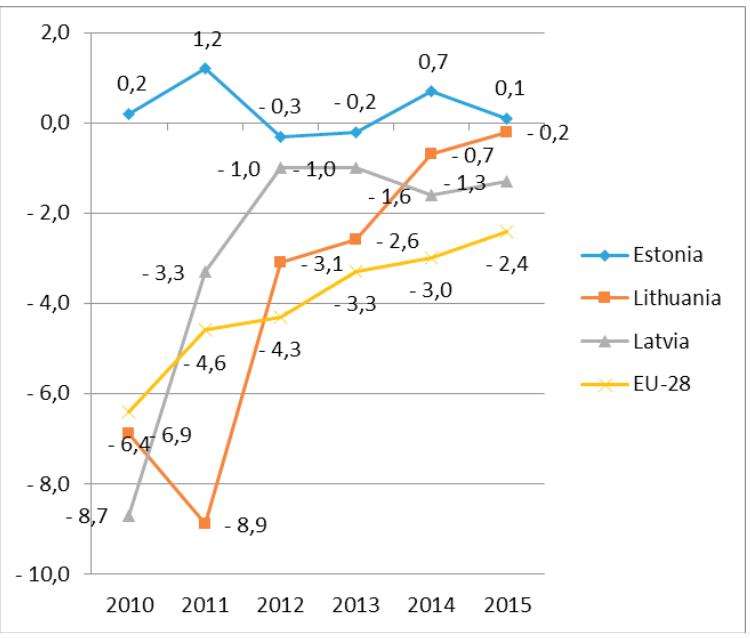

Source: Own elaboration based on Eurostat 2017 statistics.

The primary characteristic of Estonia's economy is a fairly stable budget. Since 2001 the budget has remained fairly balanced, and since with surplus increasing due to GDP growth. The crisis in Estonia came to light so early because as compared to the other Baltic States, accumulated budget surpluses from previous years had softened its situation. Estonian budget deficits occurred in 2008 and 2009. From 2010 to 2011, Estonia regained its prior balance of income surpluses over expenditures. Economic growth in 2010 was $2.3 \%$ of GDP, due in large part to increased exports. Labor productivity grew faster than real Estonian wages since companies became competitive on world markets (Parts, 2013). At the end of the year, increased consumption and investment had positive dynamics, which in subsequent years replaced the drop in exports. Despite the crisis, Estonia joined the Eurozone in 2011. Since then, maintaining the budgetary discipline has been a priority of the Estonian government. Its open economy, liberal economic policies, favorable climate for entrepreneurship, and tax and banking system have kept budget deficit low. Between 2010 and 2015 Estonia's maximum budget deficit was $-0.3 \%$ in 2012 ; this did not exceed the convergence criteria. Estonia's economy's return on the path of growth after the financial crisis was due to creating conditions conducive to business growth. As a result, Estonia experienced a surplus of $0.7 \%$ in GDP in 2014 and a surplus of $1.4 \%$ by 2015 . 
Budget Deficit and Public Debt in the Baltic States in 2010-2015

Table 1 Estonian Budget Deficit and GDP Growth

\begin{tabular}{|l|c|c|c|c|c|c|}
\hline \multicolumn{1}{|c|}{ Indicators } & 2010 & 2011 & 2012 & 2013 & 2014 & 2015 \\
\hline $\begin{array}{l}\text { Public sector revenue (\% of } \\
\text { GDP) }\end{array}$ & 40,7 & 38,6 & 39,0 & 38,4 & 39,1 & 40,5 \\
\hline $\begin{array}{l}\text { Public sector expenditure (\% of } \\
\text { GDP) }\end{array}$ & 40,5 & 37,4 & 39,3 & 38,5 & 38,5 & 40,4 \\
\hline GDP (increase in\%) & 2,3 & 7,6 & 4,3 & 1,4 & 2,8 & 1,4 \\
\hline Budget deficit (\% of GDP) & 0,2 & 1,2 & $-0,3$ & $-0,2$ & 0,7 & 0,1 \\
\hline EU-28 Budget deficit (\% of GDP) & $-6,4$ & $-4,6$ & $-4,3$ & $-3,3$ & $-3,0$ & $-2,4$ \\
\hline
\end{tabular}

Source: Own elaboration based on Eurostat 2017 statistics.

Latvia has been in the euro area since January 2014. Between 2012 and 2013, Latvia's budget deficit was -1\% of GDP: much lower than it had been between 2010 and 2011. Before the 2008 financial crisis, the Latvian budget was nearly balanced. Indeed, in the years between 2002 and 2007, the deficit did not exceed 2.3\%. However, after the financial crisis, Latvia's deficit reached $-8.7 \%$ of GDP in 2010. However, the Latvian economy improved its GDP growth by $6.4 \%$ in 2011, and fiscal policy changes have increased the inflow of investment. During the crisis, Latvia experienced the worst collapse of all of the countries in the region, losing $25 \%$ of its GDP between 2008 and 2010. There were drastic structural changes in the public sector, as well as a $26 \%$ reduction in the average wage in the public sector. With international and financial support, however, it introduced an adjustment program, which allowed it to pay its obligations to the International Monetary Fund long before the deadline. As a result, the European Commission reports that economic growth accelerated to $4 \%$ in 2012 . Good economic condition and stable fiscal policy kept Latvia's budget deficit below $2 \%$ by the end of our study's temporal period.

Table 2 Latvian Budget Deficit and GDP Growth

\begin{tabular}{|l|c|c|c|c|c|c|}
\hline \multicolumn{1}{|c|}{ Indicators } & 2010 & 2011 & 2012 & 2013 & 2014 & 2015 \\
\hline Public sector revenue (\% of GDP & 36,3 & 35,7 & 36,3 & 35,9 & 35,9 & 35,8 \\
\hline $\begin{array}{l}\text { Public sector expenditure (\% of } \\
\text { GDP) }\end{array}$ & 45,0 & 39,0 & 37,3 & 36,9 & 37,5 & 37,0 \\
\hline GDP (increase in\%) & $-3,8$ & 6,4 & 4,0 & 2,6 & 2,1 & 2,7 \\
\hline Budget deficit (\% of GDP) & $-8,7$ & $-3,3$ & $-1,0$ & $-1,0$ & $-1,6$ & $-1,3$ \\
\hline EU-28 Budget deficit (\% of GDP) & $-6,4$ & $-4,6$ & $-4,3$ & $-3,3$ & $-3,0$ & $-2,4$ \\
\hline
\end{tabular}

Source: Own elaboration based on Eurostat 2017 statistics.

Lithuania joined the Eurozone only in January 2015, when it was obliged to fulfill all of the convergence criteria, including keeping the budget deficit below $3 \%$ of GDP. In 2013 Lithuania's public finance deficit was at $-2.2 \%$ of GDP. Lithuania's maximum budget deficit in our temporal period occurred in 2011 when it had a deficit of $-8.9 \%$ of GDP. This was the highest deficit of all the Baltic States considered in our analysis. After the crisis in Lithuania, there were major changes 
to fiscal policy, including tax increases and resignation from tax relief. However, budget revenue was still low. It was only in 2012 that public sector expenditure fell and the budget deficit began to decrease, thanks in part to budget cuts related to social expenses like pensions and benefits. Exports helped boost Lithuania's economy in 2010, generating 31.5\% of GDP. Lithuania's responsible public finance policy decreased the budget deficit to $-0.2 \%$ by 2015 .

Table 3 Lithuanian Budget Deficit and GDP Growth

\begin{tabular}{|l|c|c|c|c|c|c|}
\hline \multicolumn{1}{|c|}{ Indicators } & 2010 & 2011 & 2012 & 2013 & 2014 & 2015 \\
\hline Public sector revenue (\% of GDP & 35,4 & 33,5 & 33,0 & 33,0 & 34,1 & 34,9 \\
\hline $\begin{array}{l}\text { Public sector expenditure (\% of } \\
\text { GDP) }\end{array}$ & 42,3 & 42,5 & 36,1 & 35,6 & 34,8 & 35,1 \\
\hline GDP (increase in\%) & 1,6 & 6,0 & 3,8 & 3,5 & 3,5 & 1,8 \\
\hline Budget deficit (\% of GDP) & $-6,9$ & $-8,9$ & $-3,1$ & $-2,6$ & $-0,7$ & $-0,2$ \\
\hline EU-28 Budget deficit (\% of GDP) & $-6,4$ & $-4,6$ & $-4,3$ & $-3,3$ & $-3,0$ & $-2,4$ \\
\hline
\end{tabular}

Source: Own elaboration based on Eurostat 2017 statistics.

\section{Public Debt in the Baltic States}

Chart 2 shows the results of analyzing the ratio of public debt to GDP. Between 2010 and 2015, none of the Baltic countries exceeded the Maastricht criteria. By 2015, Lithuania was the worst case, where public debt was 42,7\% of GDP. Except for 2013, the debt-to-GDP ratio increased steadily in Lithuania over our study's temporal period. Except for 2012, the trend in Latvia was different. Estonia was the most stable of the Baltic States, where the ratio of debt to GDP slightly worsened in 2011 but fell from $10.7 \%$ to $10.1 \%$ by 2015 .

\section{Chart 2 Comparison of Public Debt Levels of Estonia, Lithuania, Latvia and Average 28 members of the EU,\% GDP}

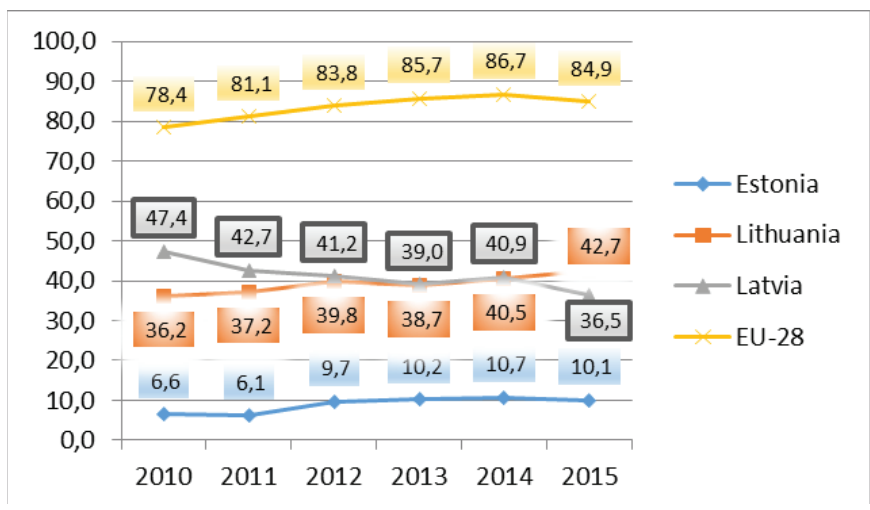

Source: Own elaboration based on Eurostat 2017. 
Comparing the Baltic states public debt with EU averages clearly demonstrates that the Baltic countries were in better financial conditions. Estonia, in particular, is an exemplary example. The main cause of high public debt in Latvia and Lithuania can undoubtedly be the occurrence of a high budget deficit. This could be avoided by decreasing budget expenditures. However, this would likely dissatisfy some electoral groups that are critical for determining government policy.

The Baltic states are similar in that public debt is taken on primarily by the central government. In the period under review, Lithuania's government took on approximately 1.5 times more debt, while Estonia's government took on almost four times more debt. It's worth noting that the debt structure in Lithuania differs from Latvia and Estonia in that it is created primarily by social security funds, which are practically absent in Estonia and Latvia. During the crisis in Lithuania, unemployment increased, and the influence of the Lithuanian State Social Insurance Fund decreased considerably. At that time, the Lithuanian parliament decided to increase pensions and Maternity and Tacit Maternity benefits as a means of handling the crisis.

\section{Table 4 Public Debt in the Baltic States According to Criterion of State Unit Incurring Debt, EUR million}

\begin{tabular}{|c|c|c|c|c|c|c|c|c|c||}
\hline & \multicolumn{3}{|c|}{ Central government } & \multicolumn{3}{c|}{ Local government } & \multicolumn{3}{c||}{ Social security funds } \\
\cline { 2 - 11 } & Estonia & Latvia & Lithuania & Estonia & Latvia & Lithuania & Estonia & Latvia & Lithuania \\
\hline 2010 & no data & no data & 9427.7 & no data & no data & 442.8 & no data & no data & 1647.5 \\
\hline 2011 & 533.0 & no data & 10641.0 & 541.3 & no data & 573.9 & 0.1 & no data & 2204.0 \\
\hline 2012 & 1937.4 & no data & 12260.0 & 566.6 & no data & 638.7 & 0.0 & no data & 2817.1 \\
\hline 2013 & 2082.3 & 8648.6 & 12540.4 & 678.5 & 1362.5 & 695.8 & 0.0 & 0.0 & 3200.5 \\
\hline 2014 & 2247.7 & 9534.6 & 13761.4 & 754.3 & 1426.0 & 754.7 & 0.0 & 0.0 & 3576.4 \\
\hline 2015 & 2221.6 & 8888.5 & 14894.7 & 728.3 & 1454.3 & 722.8 & 0.0 & 0.0 & 3762.3 \\
\hline
\end{tabular}

Source: Own elaboration based on Eurostat 2017.

The figures in Table 4 also show that in Latvia, local authorities incurred significantly more debt than Lithuania and Estonia respectively.

A large part of the state's budget includes not only the size of the public debt but also the costs of servicing it. Chart 3 shows the dynamics of changes in public debt 
servicing costs between 2010 and 2015 in the Baltic states. The highest interest was paid by Lithuania; the smallest, by Estonia. In Lithuania, costs increased steadily until 2012, after which they gradually declined.

\section{Chart 3 Baltic States' Interest for Public Debt, EUR million}

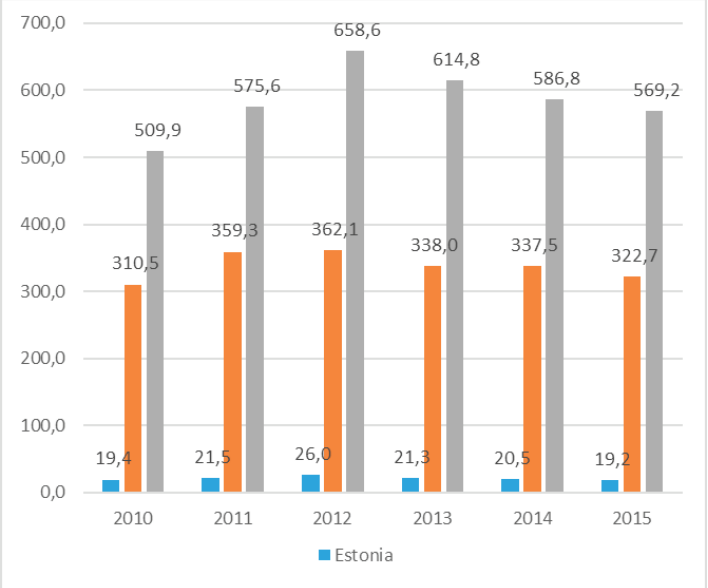

Source: Own elaboration based on Eurostat 2017.

In 2014, Lithuania categorically resigned from borrowing from the International Monetary Fund, claiming it cared more about its prestige and independence. This had a strong influence on foreign direct investment. This refusal may have also been linked to restrictive IMF conditions that require a consistent reduction in de facto government spending, a budget deficit, and political actions such as changes to the tax system.

While the interest rate on a loan from the IMF was about 3\% per year, Lithuania paid anywhere from $5 \%$ to $9 \%$ of interest on loans from commercial banks. This occurred at the same time that Latvia received an attractive loan from the IMF. Lastly, Estonia had the lowest debt servicing costs in the reviewed period.

\section{Deficit, Public Debt, and GDP in the Baltic States}

It is difficult to uniquely determine the correlation between deficit, public debt, and GDP growth in the Baltic countries. It is clear that 2011 was the year of the biggest growth in GDP in all Baltic states, after which there is the tendency towards decline. However, this did not always result in an increase in deficit or public debt. It is worth remembering that high GDP growth in 2011 was in part a result of exceptionally unfavorable conditions in the previous year. 
As shown in Chart 4, there is no direct correlation between GDP growth and deficit and public debt in Estonia. In 2012, public debt increased by 1.5 times in Estonia, while this year saw a decline in GDP growth of over 3\% as compared to the previous year when the budget had a surplus.

Chart 4 Budget Deficit, Public Debt and GDP in Estonia in 2010-2015

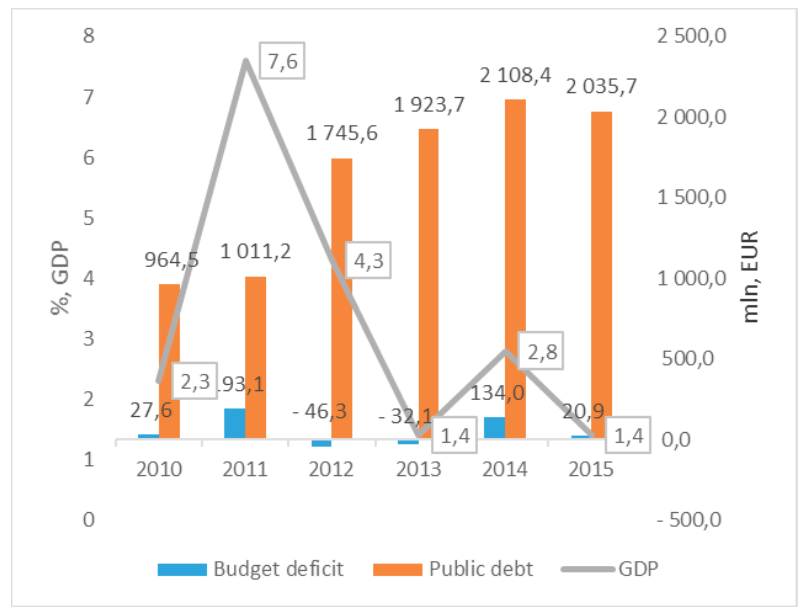

Source: Own elaboration based on Eurostat 2017.

The period between 2010 and 2015 is characterized by relative stability in Estonian politics, where successive governments formed the pro-market Reform Party and its partners.

According to forecasts of the International Monetary Fund, Estonia's public debt will continue to fall consistently in the coming years. According to IMF experts, effective Estonian fiscal policy after the crisis could even contribute to a fall in public debt below 8\% of GDP between 2020 and 2021 (IMF Report, 2016: 26).

As a result of favorable fiscal policies, Latvia has achieved relatively stable economic growth and has managed to stop the growth of its public debt and has reduced the budget deficit. 
Stanisław Pilżys, Robert Aliukonis

\section{Chart 5 Budget Deficit, Public Debt and GDP in Latvia in 2010-2015}

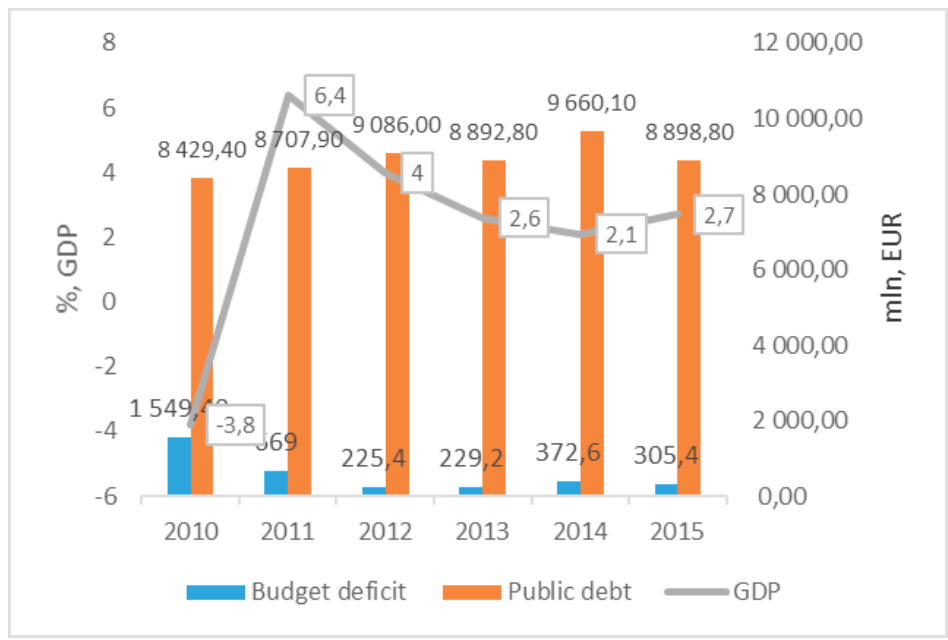

Source: Own elaboration based on Eurostat 2017.

Chart 5 shows that Latvian public debt between 2010 and 2015 was fairly stable, with the deficit falling most significantly between 2010 and 2013 before leveling out.

Chart 6 Budget Deficit, Public Debt and GDP in Lithuania in 2010-2015

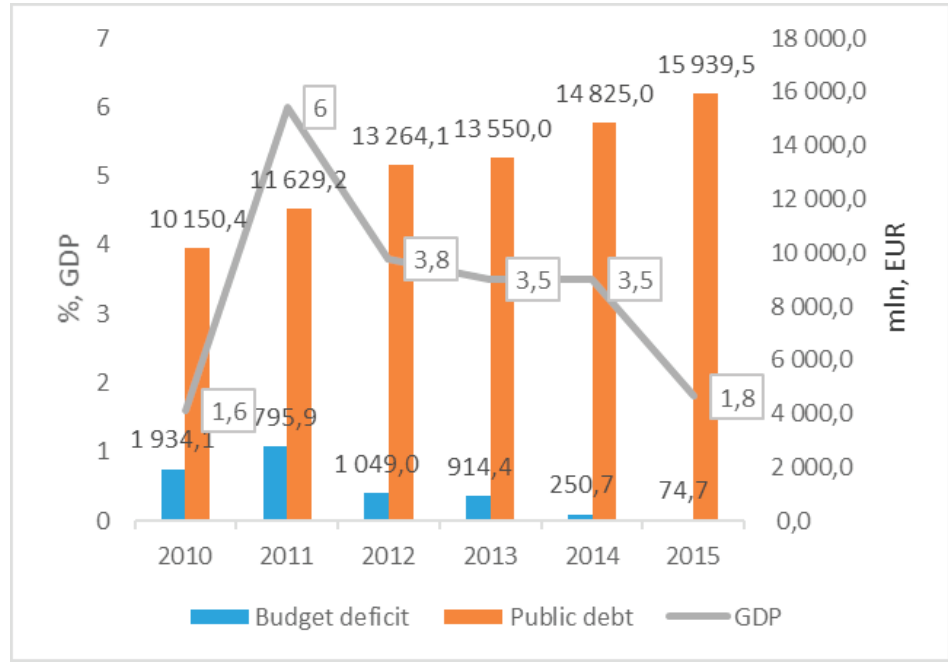

Source: Own elaboration based on Eurostat 2017.

On the other hand, Chart 6 shows that despite a gradual reduction of the budget deficit, Lithuania failed to successfully halt the growth of its public debt. Since 
2011, GDP growth has also declined steadily, which has exacerbated public debt, at least to some extent.

According to Eurostat forecasts, populations in the Baltic states aging less quickly than Slovakia and other southern EU countries. Demographic changes, however, will be one of the factors that will be detrimental to state spending; this will in turn translate to deficit and public debt. In the long-term, public debt may grow as the number of people paying taxes will decrease and expenditures on pensions, social security, and healthcare increase.

\section{Conclusions}

Disaggregating the Baltic States from other Soviet countries is critical for future analyses. Countries such as Poland, Slovakia, the Czech Republic and Hungary were more independent and financially viable as compared to 1991. The Baltic states, on the other hand, were able to build their institutions from the outset without public baggage, but the lack of experience in building a new financial infrastructure proposed a serious risk to their economies. The Baltic countries have chosen an economic model similar to Scandinavian countries. At present, even the Baltic banking system is dominated by Nordic banks. In this paper, we attempted to analyze the state of public finances in the Baltic states after the crisis in 2010 and 2015. Economists often blame the deterioration of public finance on economic recession.

Estonia, which meets the convergence criteria, had the most favorable results with the lowest budget deficit within the EU. It is the only country that generated budget surpluses, and it had the most balanced budget. Despite doubling its public debt during the period considered, its debt was the smallest of all Baltic states when considering debt ratio to GDP. This is because Estonia prioritized its economic policy of balancing budgets, which, in turn, translated to avoiding large state debt.

Latvia exceeded the budget deficit outlined by the convergence criteria between 2010 and 2011. In 2010, the deficit reached $-8.7 \%$ of GDP and was higher than the EU average, which was $-6.4 \%$. Over the years, the situation has improved significantly, and the deficit has since not exceeded $-2 \%$ of GDP. Latvian public debt remained stable in the period under review. It is worth noting that in Latvia, a significant portion of the public debt was generated by local authorities.

Between 2010 and 2012, Lithuania did not meet the convergence criteria: the deficit was above 3\% of GDP and exceeded the EU average. Changes in the public finance sector stabilized the situation, with reduction of the budget deficit between 2012 to 
2015 that amounted to $-0.2 \%$ of GDP by 2015 . Lithuanian public debt grew the most of the Baltic States, due in part to relatively expensive loans. From 2010 to 2015, the debt increased by more than 1.5 times its amount, with the debt from social security funds rising more than 2 times its previous amount. Even so, Lithuania still met the convergence criteria for public debt.

Our statistical analysis reveals no high correlation between the growth of GDP and reduction of the budget deficit in the three countries. This largely depends on the public finance policy pursued by the government. When comparing the public debt of the Baltic States with the countries of the old EU, we must remember that the Baltic countries did not inherit debt after the Soviet period. Their debt, while relatively recent, grew at a rapid pace. At the moment, the Baltic countries are not in debt to the same degree as other countries of the old EU. But the debt, especially in Lithuania, is constantly growing, and a sound economic policy is needed to maintain a stable situation. In particular, Latvia's policy implementation after the recent global financial crisis must be considered in future recommendations. Appropriate fiscal policy, deficit reduction, and public debt are important in order to avoid an income trap that could cause considerable stagnation among the Baltic States.

\section{References}

Ciborowski, R.: Międzynarodowy transfer technologii a innowacyjność krajów Europy ŚrodkowoWschodniej (International Technology Transfer and Innovation of the Central and Eastern European Countries), Bialystok: PTE, 2016.

Daniłowska, A.: Dług publiczny - jego struktura, przyczyny, rozmiary i skutki (Public debt - its structure, causes, dimensions and effects), Zeszyty Naukowe Szkoły Głównej Gospodarstwa Wiejskiego w Warszawie. Ekonomika i Organizacja Gospodarki Żywnościowej (Scientific Papers of the Warsaw University of Life Sciences and Economics in Warsaw. Economics and Organization of Agri-Food Sector) no. 9 (2008).

Gaudemet, P. M.: Finanse publiczne (Public Finance), Warszawa: PWN, 1990.

Gruszewska, E., Rozwój i czynniki rozwoju gospodarczego (Development and factors of economic development), in: Meredyk, K. (ed.): General economics, Bialystok: Wydawnictwo Uniwersytetu w Białymstoku, 2007.

Parts, J.: Estonia and the European Debt Crisis, Cato Journal no. 2 (2013).

Kańduła, S., Kijek, I., Wybrane zagadnienia finansów publicznych (Selected issues of public finances), Poznań: Wydawnictwo Akademii Ekonomicznej w Poznaniu, 2006.

Keynes, J.M.: Ogólna teoria zatrudnienia, procentu i pieniądza (The General Theory of Employment, Interest and Money), Warszawa: Wydawnictwo Naukowe PWN, 2003. 
Nasiłowski, M.: System rynkowy podstawy mikro- i makro ekonomii (Market system of the basics of micro- and macroeconomics), Warszawa: Key Text, 1998.

Owsiak, S.: Finanse publiczne. Teoria i praktyka (Public finance. Theory and practice), Warszawa: PWN, 1999.

Owsiak, S.: Finanse publiczne. Teoria i praktyka (Public finance. Theory and practice), Warszawa: PWN, 2005.

Samuelson, P.A., Nordhaus, W.D.: Ekonomia (Economics), Warszawa: PWN, 1995.

Siwińska-Gorzelak, J.: Dług publiczny a wzrost gospodarczy (Public debt and economic growth), Warszawa: Scholar, 2015.

Waśniewski, K.: Czy dług publiczny musi rosnąć? (Does public debt have to grow?), Warszawa: Scholar, 2014.

Zagóra-Jonszta, U.: Dług publiczny w nowych krajach Unii Europejskiej (Public Debt in New Countries of the European Union), in: Grynia, A. (ed.): Wybrane aspekty rozwoju i konkurencyjności nowych krajów członkowskich Unii Europejskiej (Selected Aspects of Development and Competitiveness of the New Member States of the European Union), Wilno: BMK Leidykla, 2015.

IMF Report, Republic of Estonia: Article IV Consultation-Press Release, 2016. www.imf.org. 